\title{
Analisis Kurikulum PAUD di Kabupaten Rejang Lebong dan Relevansinya Terhadap Kurikulum Prodi PIAUD IAIN Curup
}

\author{
Siti Zulaiha \\ Institut Agama Islam Negeri (IAIN) Curup \\ sitizulaiha@iaincurup.ac.id \\ Baryanto \\ Institut Agama Islam Negeri (IAIN) Curup \\ baryanto2014@yahoo.co.id
}

\begin{abstract}
This research is motivated by the importance of conducting an analysis related to the implementation of the curriculum in PAUD in Rejang Lebong Regency, this is because the curriculum that is applied is not uniform along with the changes in existing regulations. In addition, it is based on the importance of analyzing the relevance of the PIAUD Study Program curriculum with the applicable curriculum in PAUD so that it can be an improvement in the future. The purpose of this study is to describe how the curriculum concept, analyze the implementation of the curriculum describes the relevance of the Early Childhood Education curriculum in Rejang Lebong District to the Curriculum for Early Childhood Islamic Education Study Program. This study is a field research that is descriptive qualitative in nature. Data sources or informants are the Head and Teacher of Early Childhood Education. Data collection techniques used are interview, observation and documentation. Data analysis begins by reducing the data that has been collected, then presented in the form of a description of the data and the final conclusion from the results and analysis that has been done. The results of this study indicate that: first, the content of the PAUD curriculum in Rejang Lebong Regency which refers to the 58 of 2009 includes PAI, Language, Cognitive, Physical, Akhlakul Karimah, Independence, Emotional Social. Whereas those referring to Ministerial Regulation 2014 of 2014 are aspects of the development of Religious and Moral Values, Motoric, Cognitive, Emotional, Language and Art. Secondly, the implementation of the PAUD curriculum in Rejang Lebong Regency in general has been in accordance with the applicable curriculum guidelines but only in teaching and learning activities that many have not used the learning model that should be applied, then the approach has not been implicitly included in the daily work plan prepared by the teacher. Third, the relevance of the PAUD curriculum to the PIAUD Study Program curriculum in general has been relevant, but the content and placement of the
\end{abstract}


components of the offered courses and their extent and depth need to be reviewed.

Keywords: PAUD Curriculum, PIAUD Curriculum

\begin{abstract}
Abstrak : Penelitian ini dilatar belakangi oleh pentingnya dilakukan analisis terkait dengan pelaksanaan kurikulum pada PAUD di Kabupaten Rejang Lebong, hal ini dikarenakan kurikulum yang diterapkan belum seragam seiring dengan perubahan peraturan yang ada. Selain itu didasari oleh pentingnya menganalisis relevansi kurikulum Prodi PIAUD dengan kurikulum yang berlaku di PAUD sehingga bisa menjadi perbaikan kedepan. Adapun tujuan penelitian ini adalah mendeskripsikan bagaimana konsep kurikulum, menganalisis pelaksanaan Kurikulum mendeskripsikan relevansi kurikulum Pendidikan Anak Usia Dini di Kabupaten Rejang Lebong terhadap Kurikulum Program Studi Pendidikan Islam Anak Usia Dini. Penelitian ini merupakan penelitian lapangan (field research) yang bersifat deskriptif kualitatif. Sumber data atau informan adalah Kepala dan Guru Pendidikan Anak Usia Dini. Teknik pengumpulan data yang digunakan yaitu interview, observasi dan dokumentasi. Analisis data diawali dengan mereduksi data yang telah dikumpulkan, kemudian disajikan dalam bentuk uraian deskripsi data dan terakhir ditarik kesimpulan dari hasil dan analisis yang telah dilakukan. Hasil penilitian ini menunjukkan bahwa : pertama, muatan kurikulum PAUD di Kabupaten Rejang Lebong yang mengacu pada Permen 58 tahun 2009 meliputi PAI, Bahasa, Kognitif, Fisik, Akhlakul Karimah, Kemandirian, Sosial Emosional. Sedangkan yang mengacu pada Permen 146 tahun 2014 yaitu aspek perkembangan Nilai Agama dan Moral, Fisik Motorik, Kognitif, Sosial Emosional, Bahasa dan Seni. Kedua, pelaksanaan kurikulum PAUD di Kabupaten Rejang Lebong secara umum telah sesuai dengan pedoman kurikulum yang berlaku hanya saja pada kegiatan belajar mengajar masih banyak yang belum menggunakan model pembelajaran yang seharusnya diterapkan, kemudian pendekatan belum secara implisit dimasukkan dalam rencana kerja harian yang disusun oleh guru. Ketiga, relevansi kurikulum PAUD terhadap kurikulum Prodi PIAUD secara umum telah relevan, akan tetapi pada muatan dan penempatan pada komponen mata kuliah yang ditawarkan dan tingkat keluasan serta kedalamannya perlu dikaji ulang.
\end{abstract}

Kata Kunci : Kurikulum PAUD, Kurikulum Prodi PLAUD

\title{
PENDAHULUAN
}

Capaian pembelajaran dan penentuan struktur dan muatan kurikulum Program Studi Pendidikan Islam Anak Usia Dini hendaknya disesuaikan dengan 
profil lulusan yang telah ditentukan yaitu menjadi Guru/Pendidik pada Lembaga Pendidikan Anak Usia Dini (TPA, KB, SPS, TK/RA), Peneliti, Desainer Pembelajaran dan Entrepreneur pada Bidang Pendidikan Anak Usia Dini.1 Namun, selain dari penyesuaian capaian pembelajaran dengan profil lulusan, hal yang harus dikaji lagi kesesuaian atau relevansi capaian pembelajaran dan struktur serta muatan kurikulum Prodi PIAUD dengan kurikulum Pendidikan Anak Usia Dini. Sehingga lulusan Prodi PIAUD dapat memenuhi tuntutan dunia kerja atau kebutuhan lembaga Pendidikan Anak Usia Dini.

Lebih lanjut untuk menganalisis relevansi kurikulum Prodi PIAUD terhadap kurikulum PAUD, peneliti seyogyanya melakukan analisis muatan kurikulum dan melihat pelaksanaan kurikulum yang diterapkan di PAUD tersebut. Berdasarkan survey awal yang peneliti lakukan kurikulum yang diterapkan di PAUD yang meliputi Kelompok Bermain, Taman Kanak-kanak dan Raudhatul Athfal di Kabupaten Rejang Lebong masih belum seragam, ada yang masih menggunakan kurikulum yang berpedoman pada Permen 58 Tahun 2009 Tentang Standar Pendidikan Anak Usia Dini dan ada yang menerapkan kurikulum sesuai dengan Permen No 146 tahun 2014 tentang Pelaksanaan Kurikulum 2013 Pendidikan Anak Usia Dini. ${ }^{2}$ Adapun rincian datanya sebagai berikut :

Tabel 1. Penggunaan Kurikulum PAUD di Kab. Rejang Lebong

\begin{tabular}{lll}
\hline No & Nama Sekolah & Kurikulum \\
\hline 1 & TK Pembina & K13 \\
\hline 2 & TK Kemala Bhayangkari & K13 \\
\hline 3 & TK 'Aisyiyah & K13 \\
\hline 4 & TK Pertiwi & K13 \\
\hline 5 & TK Pembina II & K13 \\
\hline 6 & TK Anak Cerdas & K13 \\
\hline 7 & TKIT Juara & K13 \\
\hline 8 & Kober Asma & K13 \\
\hline 9 & Kober Mekar Sari & Permen 58 \\
\hline 10 & Kober Islam Baiturahim & K13 \\
\hline 11 & Kober Alirsyad & Permen 58 \\
\hline 12 & Kober Azzah & Permen 58 \\
\hline 13 & Kober Mentari & Permen 58 \\
\hline
\end{tabular}




\begin{tabular}{|c|c|c|}
\hline 14 & Kober Alikhlas & Permen 58 \\
\hline 15 & Kober Annur & K13 \\
\hline 16 & Kober Kasih Ibu & K13 \\
\hline 17 & Kober Mekar Jaya & K13 \\
\hline 18 & Kober Lestari & K13 \\
\hline 19 & Kober Teratai & K13 \\
\hline 20 & Kober Kita Bersama & K13 \\
\hline 21 & RA Rabbi Radiyah & K13 \\
\hline 22 & RA Umatan Wahidah & K13 \\
\hline 23 & RA Khoiru Ummah & Permen 58 \\
\hline 24 & RA Baitul Makmur & Permen 58 \\
\hline
\end{tabular}

Sumber: Dokumen HIMPAUDI Rejang Lebong 2017.

Adapun penelitian terdahulu yang telah dilakukan berkaitan dengan pelaksanaan kurikulum diantaranya dilakukan oleh Dewi Mahmudah, yang berjudul : "Implementasi Kurikulum 2013 Pendidikan Anak Usia Dini dalam Pembelajaran". Hasil penelitiannya menunjukkan bahwa :

1. Perencanaan implementasi kurikulum 2013 PAUD di 2 lembaga PAUD dengan penyusunan Program Semester, Rencana Pelaksanaan Pembelajaran Mingguan, Rencana Pelaksanaan Pembelajaran Harian, dan perencanaan penilaian. TK ABA Ngampilan telah merencanakan alat dan bahan yang beragam, akan tetapi di TK Budi Mulia Dua masih ada yang menggunakan lembar kerja anak.

2. Proses pelaksanaan pembelajaran dengan pendekatan saintifik dilakukan saat pijakan sebelum main dan saat kegiatan main. Saat tahap mengkomunikasikan, TK ABA Ngampilan, guru mampu memberikan penegasan kepada anak, sedangkan di TK Budi Mulia Dua Yogyakarta masih ada beberapa guru yang belum memberikan penegasan saat anak mengkomunikasikan hasil temuannya.

3. Proses penilaian otentik dilakukan dengan penilaian harian yang menggunakan teknik pengumpulan data, kompilasi data mingguan, kompilasi data bulanan dan laporan perkembangan anak.

4. Kendala yang dihadapi dan solusi dalam mengimplementasikan kurikulum 2013 PAUD di TK ABA Ngampilan dan TK Budi Mulia Dua Yogyakarta berbeda. Kendalanya antara lain : format perencanaan (Prosem, RPPM, RPPH dan Penilaian) yang rumit, pendekatan saintifik hanya dilakukan saat pembelajaran saja, proses 
saintifik yang terekam selama bermain, kurangnya pengetahuan dalam tema dan subtema dan kurangnya pengolahan data penilaian. ${ }^{3}$

Selain itu juga penelitian yang dilakukan oleh Roudlotun Ni'mah, "Pengembangan Kurikulum Pendidikan Anak Usia Dini" (Studi Kasus di TK Islam An-Nuur Purwosar Bojonegoro) dengan hasil penelitian menunjukkan bahwa penerapan konsep pengembangan kurikulum TK Islam An-Nur dalam metode pembelajaran dengan pendekatan Beyond Centers And Circle Time (BCCT)/ metode SELING. ${ }^{4}$ Berikutnya dilakukan pula oleh Tri Andiyanto dengan judul penelitian : "Peran Guru dalam Implementasi Kurikulum 2013: Studi pada TK Mentari Kec. Abung Selatan Kab. Lampung Utara", hasil penelitian menunjukkan bahwa :

1. Guru melakukan diskusi dalam proses penyusunan RPP;

2. Guru menyusun RPP melalui langkah-langkah yang sesuai;

3. Guru melaksanakan pembelajaran secara rinci;

4. Guru sebagai fasilitator;

5. Guru memberikan pendidikan karakter;

6. Guru membimbing siswa dalam belajar sesuai dengan pendekatan saintifik;

7. Guru memilih dan menggunakan metode, media, dan sumber belajar yang bervariasi;

8. Guru melakukan penilaian otentik;

9. Guru memilih dan menggunakan teknik penilaian yang bervariasi. ${ }^{5}$

Dari beberapa penelitian di atas terdapat hal yang menarik untuk dikaji ulang atau dilakukan penelitian lanjutan yang berkenaan dengan proses penyusunan dan implementasi kurikulum PAUD. Kemudian dengan diadakannya penelitian lanjutan tentunya dengan pertimbangan bahwa terdapat perbedaan pada penelitian yang akan dilakukan dengan hasil penelitian yang sudah ada. Adapun perbedaan yang dimaksudkan berkaitan dengan apa yang menjadi fokus penelitian berkaitan dengan relevansi kurikulum PAUD dengan kurikulum Prodi PIAUD sehingga kontribusi dari penelitian dapat dijadikan perbaikan pengembangan dan pelaksanaan kurikulum pada masa yang akan

3 Dewi Mahmudah, Implementasi Kurikulum 2013 Pendidikan Anak Usia Dini dalam Pembelajaran (Yogyakarta : Prodi PGRA, Pascasarjana UIN Sunan Kalijaga, 2016), hal.256

4 Roudlotun Ni'mah, Pengembangan Kurikulum Pendidikan Anak Usia Dini (Studi Kasus di TK Islam An- Nuur Purwosari Bojonegoro) Jurnal Pendidikan Islam : Al Ulya Volume 2 Nomor 1, edisi Januari - Juni 2017, hal. 25

5 Tri Andiyanto, "Peran Guru Dalam Implementasi Kurikulum 2013: Studi Pada TK Mentari Kec. Abung Selatan Kab. Lampung Utara" , Jurnal Elementary, Vol. 3 Edisi JanuariJuni 2017, hal. 77 
datang. Pada ketiga penelitian di atas dilakukan penelitian tentang implementasi kurikulum 2013 dan metode yang diterapkan dalam kurikulum PAUD, sedangkan penelitian yang dilakukan ini ingin mengungkapkan pula bagaimana relevansi kurikulum PAUD di Kabupaten Rejang Lebong terhadap kurikulum Prodi PIAUD IAIN Curup atau dengan kata lain hasil penelitian akan dijadikan bahan pertimbangan dalam perbaikan kurikulum Program Studi Pendidikan Islam Anak Usia Dini ke depan. Berdasarkan hal-hal tersebut maka yang menjadi tujuan penelitian ini yaitu untuk menganalisis bagaimana konten kurikulum PAUD di Kabupaten Rejang Lebong, mendeskripsikan pelaksanaan kurikulum PAUD di Kabupaten Rejang Lebong dan menganalisis bagaimana relevansinya terhadap kurikulum Prodi PIAUD IAIN Curup.

\section{LANDASAN TEORI}

\section{Kurikulum Prodi PIAUD}

1. Kerangka Kualifikasi Nasional Indonesia (KKNI)

Kurikulum Prodi PIAUD menyesuaikan dengan KKNI yang diatur oleh Peraturan Presiden Nomor 8 Tahun 2012. Dalam peraturan tersebut, pada Pasal 1 ayat (1), dijelaskan bahwa yang dimaksud dengan Kerangka Kualifikasi Nasional Indonesia (KKNI) adalah kerangka penjenjangan kualifikasi kompetensi yang dapat menyandingkan, menyetarakan, dan mengintegrasikan antara bidang pendidikan dan bidang pelatihan kerja serta pengalaman kerja dalam rangka pemberian pengakuan kompetensi kerja sesuai dengan struktur pekerjaan di berbagai sektor. ${ }^{6}$

Secara ringkas penyusunan Kurikulum Pendidikan Tinggi (KPT) berdasarkan KKNI dan SNPT 2014 melalui 4 tahap, yaitu:

a. Menentukan Profil Lulusan dan Capaian Pembelajaran (CP)

b. Memilih dan merangkai Bahan Kajian

c. Menyusun Mata Kuliah, Struktur Kurikulum, dan menentukan SKS

d. Menyusun Rencana Pembelajaran

2. Capaian Pembelajaran Prodi PIAUD

Capaian Pembelajaran Prodi Pendidikan Islam Anak Usia Dini yang ditetapkan mengacu pada capaian pembelajaran (CP) yang telah ditetapkan oleh DIKTI dan pencirian (keunggulan) Prodi Pendidikan Islam Anak Usia Dini berdasarkan pada 4 unsur pokok dari KKNI dan SNPT 2014 yaitu Sikap, Penguasaan Pengetahuan, Ketrampilan Umum dan Ketrampilan

6 Peraturan Presiden Republik Indonesia Tentang Kerangka Kualifikasi Nasional Indonesia No 8 Tahun 2012, hal. 1 
Khusus. Berdasarkan Capaian Pembelajaran sesuai dengan Profil Lulusan, maka disusunlah Mata Kuliah berdasarkan rumpun keilmuan sebagai berikut

Tabel 2. Daftar mata kuliah berdasarkan rumpun keilmuan Prodi PIAUD IAIN Curup

\begin{tabular}{|c|c|c|c|}
\hline \multirow[b]{2}{*}{ NO } & \multirow{2}{*}{$\begin{array}{l}\text { BASIS ILMU } \\
\text { PENGETAHUAN, } \\
\text { TEKNOLOGI \& } \\
\text { SENI }\end{array}$} & \multicolumn{2}{|c|}{ RUMPUN ILMU } \\
\hline & & BIDANG & BAGIAN \\
\hline 1 & Utama & Ilmu Dasar PIAUD & $\begin{array}{l}\text { Kesehatan dan Gizi } \\
\text { Teori Belajar dan } \\
\text { Pembelajaran } \\
\text { Neurosains PAUD } \\
\text { Dasar-dasar PAUD } \\
\text { Pembelajaran Tematik } \\
\text { Terpadu } \\
\text { Metode Pengembangan } \\
\text { Kognitif, dan Kreativitas } \\
\text { Metode Pengembangan } \\
\text { Bahasa Pengungan } \\
\text { Pengelolaan Lingkun } \\
\text { Belajar } \\
\text { Metode Pengembangan } \\
\text { Sosial, Agama, Moral dan } \\
\text { Disiplin } \\
\text { Metode Pengembangan } \\
\text { Emosi dan Spritual } \\
\text { Pengenalan Aksara AUD } \\
\text { Deteksi Dini Tumbuh } \\
\text { Kembang AUD } \\
\text { Bermain dan Permainan } \\
\text { AUD Pengembangan Bakat dan } \\
\text { Minat AUD } \\
\text { Bercerita dan Mendongeng } \\
\text { Layanan AUD Kebutuhan } \\
\text { Khusus Anatis } \\
\text { Perkembangan AUD } \\
\text { Bahasa Arab Untuk Anak } \\
\text { Usia Dini } \\
\text { Pendidikan Inklusi dalam } \\
\text { Pendidikan AUD } \\
\text { Bahasa Inggris Untuk Anak }\end{array}$ \\
\hline
\end{tabular}




\begin{tabular}{llll} 
& BASIS ILMU & \multicolumn{2}{c}{ RUMPUN ILMU } \\
NO & $\begin{array}{l}\text { PENGETAHUAN, } \\
\text { TEKNOLOGI \& } \\
\text { SENI }\end{array}$ & BIDANG & BAGIAN \\
\hline
\end{tabular}

Usia Dini

Sosiologi Pendidikan

Pembelajaran Praktik

Ibadah bagi Anak Usia Dini

Pemberdayaan Masyarakat

dalam Penyelengaraan

PAUD

Matematika AUD

Pendidikan Seksualitas

AUD

Outbond Kids

Pengembangan Profesi

Guru

Edupreneurship

\begin{tabular}{ll}
\hline Ilmu Kesehatan & Olahraga dan Senam untuk \\
Jasmani & AUD \\
Ilmu Seni & Pembelajaran Seni Musik \\
& dan Suara \\
& Pendidikan Seni Rupa \\
& AUD \\
& Pembelajaran Seni Tari \\
\hline Teknologi & Aplikasi Komputer \\
& Media Pembelajaran \\
\hline Kepemimpinan & Kepemimpinan dan \\
& Supervisi Pendidikan AUD \\
\hline Alat penelitian & Penelitian Tindakan Kelas \\
& Statistik Pendidikan \\
& Metode \\
& Pendidikan Penelitian \\
\hline Ilmu Psikologi & Psikologi Perkembangan \\
& Anak AUD \\
& Kecerdasan Majemuk \\
& Psikologi Pendidikan \\
& Bimbingan Konseling \\
\hline Strategi Pembelajaran AUD \\
& Model-model Pembelajaran \\
& PAUD \\
\hline Kurikulum Pembelajaran \\
& AUD Pendidikan \\
& Pengembangan Perangkat \\
& Pembelajaran AUD \\
& Micro Teaching \\
&
\end{tabular}




\begin{tabular}{|c|c|c|c|}
\hline \multirow{2}{*}{ NO } & \multirow{2}{*}{$\begin{array}{l}\text { BASIS ILMU } \\
\text { PENGETAHUAN, } \\
\text { TEKNOLOGI \& } \\
\text { SENI }\end{array}$} & \multicolumn{2}{|c|}{ RUMPUN ILMU } \\
\hline & & BIDANG & BAGIAN \\
\hline \multirow{7}{*}{2} & \multirow{7}{*}{ Pendukung } & & $\begin{array}{l}\text { Pendidikan Anti Korupsi } \\
\text { KPM } \\
\text { Evaluasi Pendidikan }\end{array}$ \\
\hline & & Karya Ilmiah & Skripsi \\
\hline & & Ilmu Manajemen & Manajemen Pendidikan \\
\hline & & Ilmu Filsafat & Filsafat Pendidikam Islam \\
\hline & & Ilmu Bahasa & $\begin{array}{l}\text { Bahasa Indonesia } \\
\text { Bahasa Arab } \\
\text { Bahasa Inggris }\end{array}$ \\
\hline & & Ilmu Keislaman & $\begin{array}{l}\text { Ulumul Qur'an } \\
\text { Ulumul Hadits } \\
\text { Fiqh } \\
\text { Fiqh Ibadah } \\
\text { Sejarah Pendidikan Islam } \\
\text { Tafsir Tarbawi } \\
\text { Hadis Tarbawi } \\
\text { Ilmu Pendidikan Islam } \\
\text { Ilmu Tauhid } \\
\text { Akhlak }\end{array}$ \\
\hline & & Humaniora & $\begin{array}{l}\text { Kewarganegaraan } \\
\text { Pancasila }\end{array}$ \\
\hline 3 & Penciri & $\begin{array}{l}\text { Kemampuan } \\
\text { pengajaran }\end{array}$ & PPL \\
\hline
\end{tabular}

Dokumentasi : KKNI Prodi PLAUD IAIN Curup

Kurikulum Pendidikan Anak Usia Dini

1. Peraturan Menteri Pendidikan Nasional Nomor 58 Tahun 2009 Tentang Standar Pendidikan Anak Usia Dini

a. Standar Isi

Struktur program kegiatan PAUD mencakup bidang pengembangan pembentukan perilaku dan bidang pengembangan kemampuan dasar melalui kegiatan bermain dan pembiasaan. Lingkup pengembangan meliputi : 1) nilai-nilai agama dan moral, 2) fisik, 3) kognitif, 4) bahasa, 5) sosial emosional. ${ }^{7}$

b. Standar Proses

1) Perencanaan

7 Salinan Permendikas No 58 Tahun 2009 Tentang Standar Pendidikan Anak Usia Dini, hal. 27 
a) Pengembangan Rencana Pembelajaran

b) Perencanaan Rencana Kegiatan Mingguan (RKM) dan Rencana Kegiatan Harian (RKH).

c) Rencana Kegiatan untuk anak usia 0-2 tahun bersifat individual. Jadwal kegiatan disesuaikan dengan jadwal harian masingmasing anak.

d) Prinsip-prinsip

(1) Memperhatikan tingkat perkembangan, kebutuhan, minat dan karakteristik anak

(2) Mengintegrasikan kesehatan, gizi, pendidikan, pengasuhan, dan perlindungan

(3) Pembelajaran dilaksanakan melalui bermain

(4) Kegiatan pembelajaran dilakukan secara bertahap, berkesinambungan, dan bersifat pembiasaan.

(5) Proses pembelajaran bersifat aktif,kreatif, interaktif, efektif, dan menyenangkan.

(6) Proses pembelajaran berpusat pada anak.

2) Pengorganisasian

3) Pelaksanaan

4) Pengorganisasian Kegiatan

a) Kegiatan dilaksanakan di dalam ruang/kelas dan di luar ruang/kelas.

b) Kegiatan dilaksanakan dalam suasana yang menyenangkan.

c) Kegiatan untuk anak usia $0-<2$ tahun, bersifat individual.

d) Pengelolaan kegiatan pembelajaran pada usia $2-<4$ tahun dalam kelompok besar, kelompok kecil dan individu meliputi inti dan penutup.

e) Pengelolaan kegiatan pembelajaran pada usia $4 \quad \leq 6$ tahun dilakukan dalam individu, kelompok kecil, dan kelompok besar meliputi tiga kegiatan pokok, yaitu pembukaan, inti dan penutup.

f) Melibatkan orang tua/keluarga. ${ }^{8}$

c. Standar Penilaian

Penilaian adalah proses pengumpulan dan pengolahan informasi untuk menentukan tingkat pencapaian perkembangan anak yang mencakup:

1) Teknik Penilaian 
Pengamatan, penugasan, unjuk kerja, pencatatan anekdot, percakapan/dialog, laporan orang tua, dan dokumentasi hasil karya anak (portofolio), serta deskripsi profil anak.

2) Lingkup

a) Mencakup seluruh tingkat pencapaian perkembangan peserta didik.

b) Mencakup data tentang status kesehatan, pengasuhan, dan pendidikan.

3) Proses

a) Dilakukan secara berkala, intensif, bermakna, menyeluruh, dan berkelanjutan.

b) Pengamatan dilakukan pada saat anak melakukan aktivitas sepanjang hari.

c) Secara berkala tim pendidik mengkaji-ulang catatan perkembangan anak dan berbagai informasi lain termasuk kebutuhan khusus anak yang dikumpulkan dari hasil catatan pengamatan, anekdot, check list, dan portofolio.

d) Melakukan komunikasi dengan orang tua tentang perkembangan anak, termasuk kebutuhan khusus anak.

e) Dilakukan secara sistematis, terpercaya, dan konsisten.

f) Memonitor semua aspek tingkat pencapaian perkembangan anak.

g) Mengutamakan proses dampak hasil.

h) Pembelajaran melalui bermain dengan benda konkret.

4) Pengelolaan hasil

a) Pendidik membuat kesimpulan dan laporan kemajuan anak berdasarkan informasi yang tersedia.

b) Pendidik menyusun dan menyampaikan laporan perkembangan anak secara tertulis kepada orang tua secara berkala, minimal sekali dalam satu semester.

c) Laporan perkembangan anak disampaikan kepada orang tua dalam bentuk laporan lisan dan tertulis secara bijak, disertai saran-saran yang dapat dilakukan orang tua di rumah.

5) Tindak lanjut

a) Pendidik menggunakan hasil penilaian untuk meningkatkan kompetensi diri.

b) Pendidik menggunakan hasil penilaian untuk memperbaiki program, metode, jenis aktivitas/kegiatan, penggunaan dan 
penataan alat permainan edukatif, alat kebersihan dan kesehatan, serta untuk memperbaiki sarana dan prasarana termasuk untuk anak dengan kebutuhan khusus.

c) Mengadakan pertemuan dengan orang tua/keluarga untuk mendiskusikan dan melakukan tindak lanjut untuk kemajuan perkembangan anak.

d) Pendidik merujuk keterlambatan perkembangan anak kepada ahlinya melalui orang tua.

e) Merencanakan program pelayanan untuk anak yang memiliki kebutuhan.'

2. Kurikulum 2013 Pendidikan Anak Usia Dini

a. Karakteristik Kurikulum 2013

Kurikulum 2013 Pendidikan Anak Usia Dini dirancang dengan karakteristik sebagai berikut :

1) Mengoptimalkan perkembangan anak yang meliputi : aspek nilai agama dan moral, fisik-motorik, kognitif, bahasa, sosial emosional, dan seni yang tercermin dalam keseimbangan kompetensi sikap, pengetahuan, dan keterampilan

2) Menggunakan pembelajaran tematik dengan pendekatan saintifik dalam pemberian rangsangan pendidikan

3) Menggunakan penilaian autentik dalam memantau perkembangan anak dan;

4) Memberdayakan peran orang tua dalam proses pembelajaran. ${ }^{10}$

b. Struktur dan Muatan Kurikulum 2013 PAUD

1) Pengertian

Struktur kurikulum 2013 Pendidikan Anak Usia Dini merupakan pengorganisasian Kompetensi Inti, Kompetensi Dasar, muatan pembelajaran, program pengembangan dan lama belajar. Adapun muatan kurikulum Pendidikan Anak Usia Dini berisi programprogram pengembangan yang terdiri dari :

a) Program pengembangan nilai agama dan moral mencakup perwujudan suasana belajar untuk berkembangnya perilaku baik yang bersumber dari nilai agama dan moral serta bersumber dari kehidupan bermasyarakat dalam konteks bermain. Indonesia Nomor 146 Tahun 2014 Tentang Kurikulum 2013 Pendidikan Anak Usia Dini, hal. 2 
b) Program pengembangan fisik-motorik mencakup perwujudan suasana untuk berkembangan kematangan kinestetik dalam konteks bermain.

c) Program pengembangan kognitif mencakup perwujudan suasana untuk berkembangnya kematangan proses berpikir dalam konteks bermain.

d) Program pengembangan bahasa mencakup perwujudan suasana untuk berkembangnya kematangan bahasa dalam konteks bermain.

e) Program pengembangan sosial-emosional mencakup perwujudan suasana untuk berkembangnya kepekaan, sikap, dan keterampilan sosial serta kematangan emosi dalam konteks bermain.

f) Program pengembangan seni mencakup perwujudan suasana untuk berkembangnya eksplorasi, ekspresi, dan apresiasi seni dalam konteks bermain. ${ }^{11}$

2) Standar Tingkat Pencapaian Perkembangan Anak (STPPA)

Standar Tingkat Pencapaian Perkembangan Anak merupakan kriteria minimal tentang kualifikasi perkembangan anak yang mencakup aspek nilai agama dan moral, fisik motorik, kognitif, bahasa, sosial-emosional, dan seni.

a) Kompetensi Inti

Kompetensi Inti (KI) pada Kurikulum 2013 Pendidikan Anak Usia Dini merupakan tingkat kemampuan untuk mencapai STPPA yang harus dimiliki peserta didik PAUD pada usia 6 tahun. STTPA bentuk kualitasnya berisi gambaran mengenai kompetensi utama yang dikelompokkan ke dalam kompetensi sikap, pengetahuan, dan keterampilan.

b) Kompetensi Dasar

Kompetensi dasar pada kurikulum 2013 pendidikan anak usia dini berisikan kemampuan dan muatan pembelajaran untuk suatu tema pembelajaran pada PAUD yang mengacu pada kompetensi inti . kompetensi dasar dikembangkan berdasarkan pada prinsip akumulatif saling memperkuat dan memperkaya antar program pengembangan.

c) Indikator Perkembangan 
Indikator perkembangan merupakan penanda perkembangan yang lebih spesifik dan terukur pada satu program pengembangan untuk memantau menilai perkembangan anak. Indikator perkembangan juga merupakan gambaran minimal mengenai ciri-ciri peserta didik yang dianggap telah mencapai kemampuan dasar pada tingkatan usia tertentu. Adapun rumusan indikator perkembangan sesuai dengan yang tertulis dalam dokumen Kurikulum 2013 Pendidikan Anak Usia Dini. ${ }^{12}$

a. Isi Program Pembelajaran PAUD

Isi program pembelajaran PAUD dipadukan dalam program pembelajaran yang mencakup bidang pembentukan perilaku yang meliputi lingkup perkembangan nilai-nilai agama dan moral, serta pengembangan sosial, emosional, dan kemandirian. Selain itu isi program pembelajaran PAUD mencakup bidang pengembangan kemampuan dasar yang meliputi perkembangan bahasa, kognitif, dan fisik. ${ }^{13}$

b. Pendekatan Pembelajaran dalam Kurikulum 2013

Adapun pendekatan yang digunakan dalam kurikulum 2013 adalah pendekatan tematik integratif, interdisipliner, intradisipliner dan multidisipliner. ${ }^{14}$ Kemudian lebih lanjut untuk metode dalam pembelajaran PAUD terdapat beberpa jenis diantaranya yaitu :

1) Bercerita

2) Demonstrasi

3) Bercakap-cakap

4) Pemberian tugas

5) Sosio drama (bermain peran)

6) Karyawista

7) Projek

8) Eksperimen. $^{15}$

12 Direktorat Pembinaan Pendidikan Anak Usia Dini Direktorat Jenderal Pendidikan Anak Usia Dini, Nonformal, dan informal Kementerian Pendidikan dan Kebudayaan tentang Kerangka Dasar dan Struktur Kurikulum 2013 Pendidika n Anak Usia Dini, hal. 11-19

13 Suyadi \& Dahlia, Implementasi dan Inovasi Kurikulum PAUD 2013 (Bandung : PT Remaja Rosdakarya, 2017), hal. 39-40.

14 Ibid., hal. 24

15 Pusat Kurikulum dan Perbukuan Badan Penelitian dan Pengembangan Kementerian Pendidikan dan Kebudayaan, Buku Panduan Pendidik Anak Usia 4-5 Tabun (Jakarta : Kemendikbud, 2015), hal. 29-30 
Adapun model yang saat ini berkembang dan digunakan oleh satuan pendidikan diantaranya:

1) Model pembelajaran dengan sudut-sudut kegiatan

2) Model pembelajaran kelompok dengan menggunakan kegiatan pengaman

3) Model pembelajaran area

4) Model pembelajaran sentra. ${ }^{16}$

c. Pelaksanaan Pembelajaran

Salah satu pendekatan pembelajaran yang digunakan dalam kurikulum 2013 adalah pendekatan tematik terpadu. Dalam model pembelajaran tematik terpadu di PAUD, kegiatan-kegiatan yang dilakukan untuk satu tema, sub tema, atau sub-sub tema dirancang untuk mencapai secara bersama-sama kompetensi sikap, pengetahuan dan keterampilan dengan mencakup sebagian atau seluruh aspek pengembangan. Pembelajaran tematik terpadu dilaksanakan dalam tahapan kegiatan pembukaan, inti dan penutup. ${ }^{17}$

d. Penilaian dalam Kurikulum PAUD

1) Teknik penilaian di PAUD menggunakan beberapa teknik sebagai berikut :

a) Observasi yang meliputi

b) Percakapan Percakapan

c) Penugasan

d) Rubrik merupakan catatan aktivitas siswa dengan menggunakan indikator sesuai rencana pembelajaran.

e) Hasil karya dapat berupa pekerjaan tangan atau karya seni

f) Portofolio

g) Alat penilaian terstandar

h) Alat penilaian yang dikembangkan sendiri. ${ }^{18}$

2) Prosedur Penilaian

Hasil akhir penilaian merupakan informasi tentang proses dan hasil belajar anak yang diperoleh dengan menggunakan berbagai teknik dan instrument penilaian Pelaporan Pencapaian

16 Ibid., hal.31-33

17 Salinan Lampiran IV Peraturan Menteri Pendidikan dan Kebudayaan Republik Indonesia Nomor 146 Tahun 2014 Tentang Kurikulum 2013 Pendidikan Anak Usia Dini, hal. 3-4.

18Ibid., hal. 120-140 
Perkembangan Anak sesuai dengan Permendikbud No 146 Tahun 2014. ${ }^{19}$

\section{METODE PENELITIAN}

Penelitian ini merupakan penelitian lapangan (field research) yang bersifat deskriptif kualitatif. Sumber data atau informan adalah Kepala dan Guru Pendidikan Anak Usia Dini. Teknik pengumpulan data yang digunakan yaitu interview, observasi dan dokumentasi.20 Analisis data diawali dengan mereduksi data yang telah dikumpulkan, kemudian disajikan dalam bentuk uraian deskripsi data dan terakhir ditarik kesimpulan dari hasil dan analisis yang telah dilakukan.21

\section{HASIL DAN PEMBAHASAN}

\section{Konsep Kurikulum PAUD di Kabupaten Rejang Lebong}

1. Struktur dan muatan Kurikulum Permen 58 Tahun 2009

Struktur program kegiatan PAUD mencakup bidang pengembangan pembentukan perilaku dan bidang pengembangan kemampuan dasar. Ruanglingkupnya meliputi pengembangan : a) nilai-nilai agama dan moral, b) fisik, c) bahasa, d) sosial emosional. muatan agama disebutkan lebih spesifik dalam bidang pengembangan perilaku akhlakul karimah dan pengembangan kemampuan dasar ditambah materi PAI yang menjadi ciri khas dari PAUD yang di bawah Kementerian Agama. Namun hal tersebut menjadi nilai tambah pada PAUD yang di bawah Kementerian Agama sekaligus menjadi daya tarik bagi para orangtua santri untuk memilih lembaga PAUD yang memiliki kurikulum tambahan materi Agama Islam terutama di Kabupaten Rejang Lebong. ${ }^{22}$

2. Struktur muatan kurikulum K13

Struktur Kurikulum : Muatan Kurikulum, KI, KD, lama Belajar. Muatan kurikulum terdiri dari 6 aspek : aspek pengembangan nilai agama dan moral, aspek pengembangan fisik motorik, aspek pengembangan

19 Leli Halimah, Pengembangan Kurikulum Pendidikan Anak Usia Dini (Bandung : PT Refika Aditama, 2016), hal. 278.

20 Sugiono, Metode Penelitian Pendidikan : Pendekatan Kuantitatif, Kualitatif, dan R\&D (Bandung: Alfabeta, 2008), hal. 66

21 Ibid., hal.337-345.

22 Observasi pada PAUD (Raudhatul Athfal) di Kabupaten Rejang Lebong, pada tanggal 06 Oktober-10 November 2018. 
kognitif, aspek pengembangan bahasa, aspek pengembangan sosial emosional, aspek pengembangan seni.23

\section{Pelaksanaan Kurikulum PAUD di Kabupaten Rejang Lebong}

Pelaksanaan pembelajaran di PAUD di Kabupaten Rejang Lebong pada dasarnya sesuai dengan pedoman yang ada baik dari Rencana Pembelajaran yang disusun maupun pelaksanaannya di kelas. Namun belum semua PAUD menggunakan model-model yaitu : model pembelajaran dengan sudut-sudut kegiatan, model pembelajaran kelompok dengan menggunakan kegiatan pengaman, model pembelajaran area, model pembelajaran sentra. ${ }^{24}$ Seyogyanya guru dapat menggunakan model-model tersebut dalam pembelajaran, selain itu juga hendaknya guru menggunakan metode, strategi pembelajaran yang memungkinkan anak untuk memilih beberapa kegiatan yang telah disediakan guru, sesuai dengan minat dan bakat anak pada hari itu. Akan tetapi yang terjadi di lapangan guru dalam mengajar "belum" menerapkan hal itu, dan guru mengajar secara klasikal dimana anak diberikan tugas yang sama tidak berdasarkan minat dan bakatnya masing-masing. ${ }^{25}$ Sehingga tidak menjadikan guru sebagai pusat pembelajaran sebaliknya siswalah yang menjadi pusat pembelajaran.

\section{Relevansi Kurikulum PAUD di Kabupaten Rejang Lebong terhadap Kurikulum Prodi PIAUD IAIN Curup}

Muatan kurikulum PAUD di Kabupaten Rejang Lebong Nilai Agama dan Moral, Fisik Motorik, Kognitif, Sosial Emosional, Bahasa Seni. ${ }^{26}$ Relevansi terhadap kurikulum Prodi PIAUD dimaksudkan disini untuk menganalisa relevan baik dari penyusunan capaian pembelajaran maupun dalam penentuan mata kuliah dan jumlah sksnya

23 Wawancara dengan Kepala PAUD (RA/TK dan Kober) dan Guru PAUD di Kabupaten Rejang Lebong yang menerapkan Kurikulum 2013 pada tanggal 11 Agustus-22 September 2018.

24 Pusat Kurikulum dan Perbukuan Badan Penelitian dan Pengembangan Kementerian Pendidikan dan Kebudayaan, Buku Panduan Pendidik..., hal. 31-33

25 Hasil observasi pada PAUD (TK, RA dan Kober) di Kabupaten Rejang Lebong dengan rentang waktu tanggal 29 September - 10 November 2018.

26 Dikutip dalam dokumentasi Kurikulum PAUD di Kabupaten Rejang Lebong pada tanggal 15 November 2018. 
Peneliti mengkaji relevansi kurikulum PAUD dengan Kurikulum Prodi PIAUD dengan melihat muatan pada kurikulum masing-masing sebagai berikut :

Tabel 3. Muatan Kurikulum PAUD dan Kurikulum Program Studi PIAUD IAIN Curup yang dikaitkan dengan Capaian Pembelajaran Prodi PIAUD

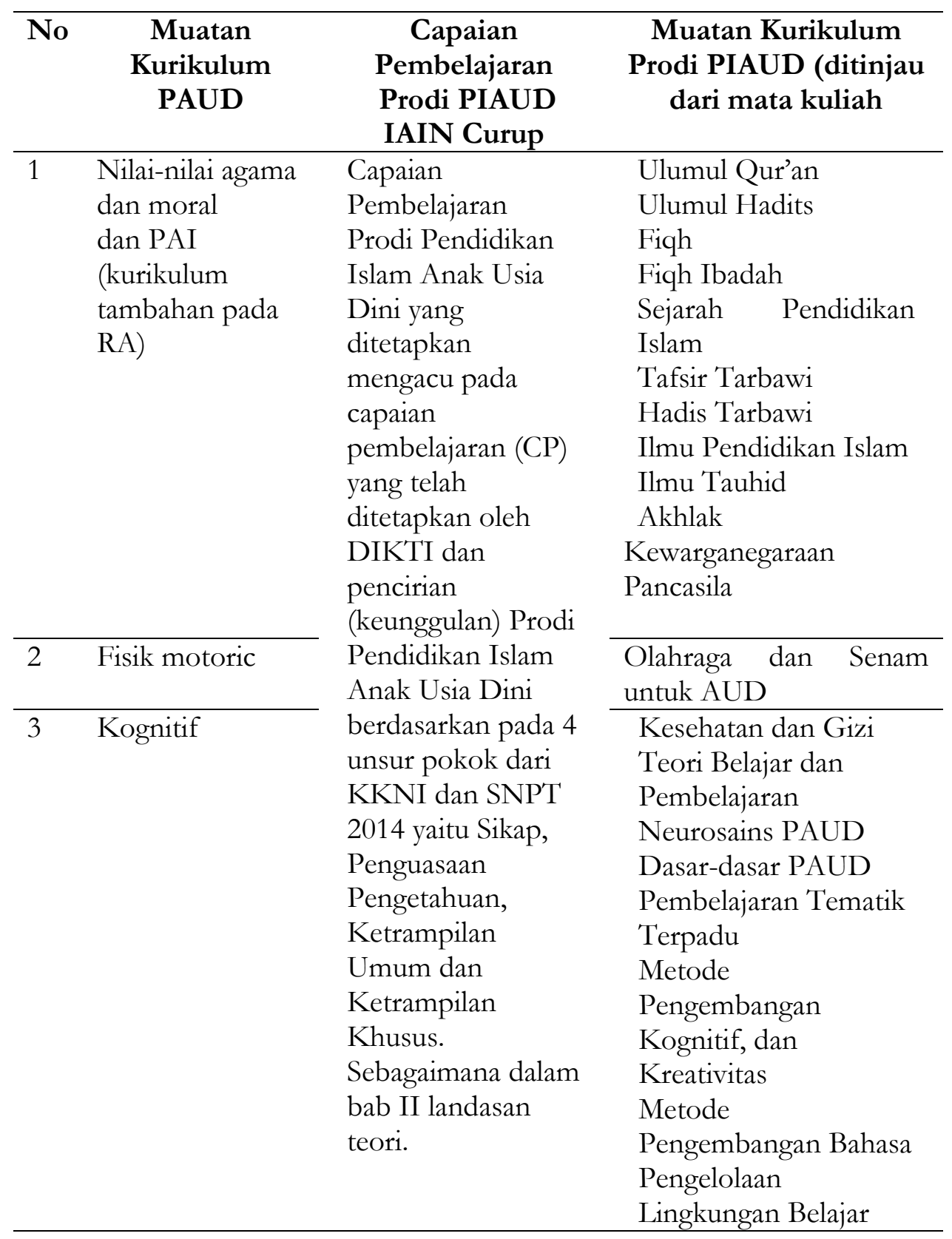




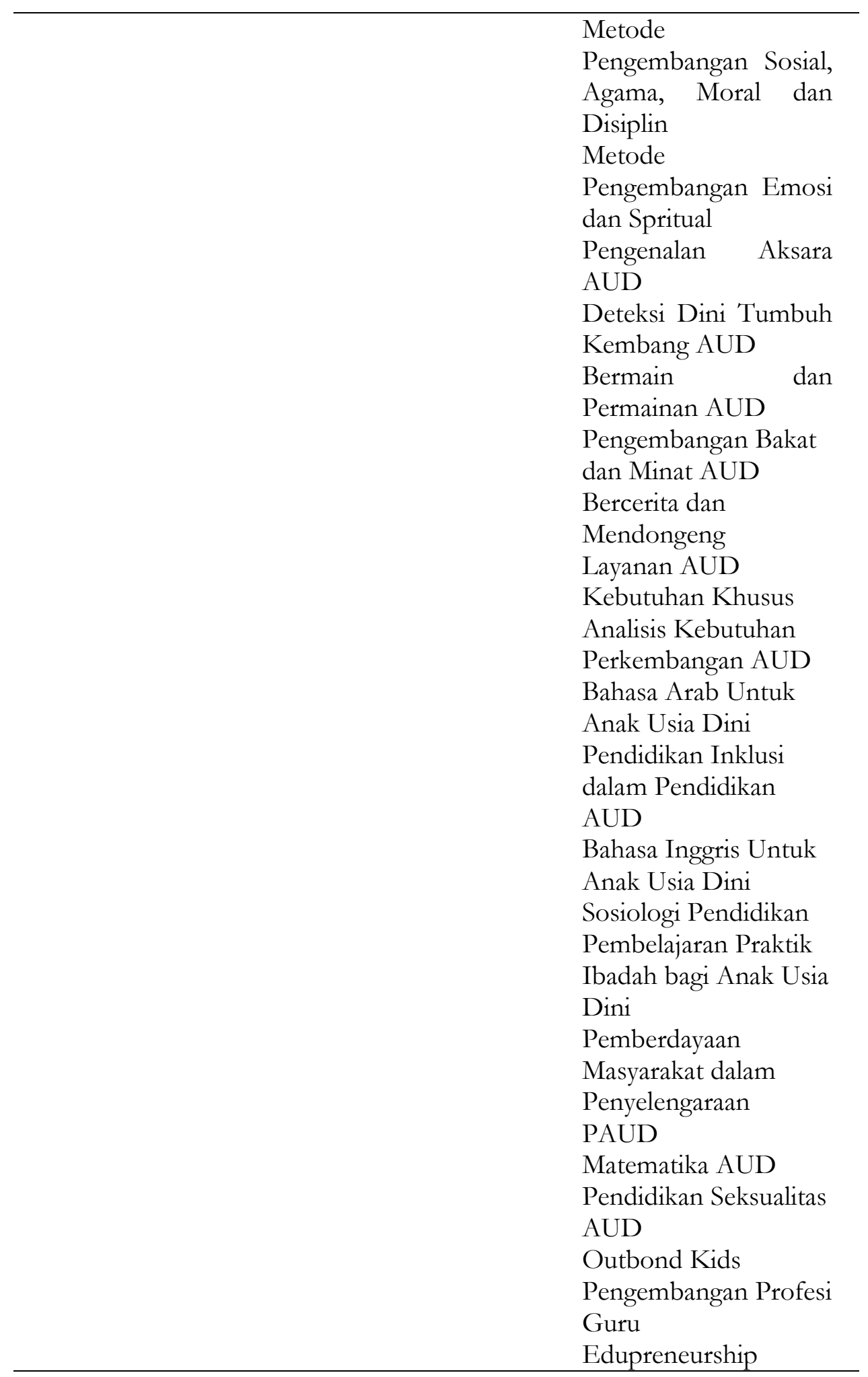




\begin{tabular}{|c|c|c|}
\hline & & $\begin{array}{l}\text { Olahraga dan Senam } \\
\text { untuk AUD }\end{array}$ \\
\hline \multirow[t]{9}{*}{4} & Sosial emosional & Psikologi \\
\hline & & Perkembangan \\
\hline & & Anak AUD \\
\hline & & Kecerdasan \\
\hline & & Majemuk \\
\hline & & Psikologi \\
\hline & & Pendidikan \\
\hline & & Bimbingan \\
\hline & & Konseling \\
\hline \multirow{3}{*}{\multicolumn{2}{|c|}{ Bahasa }} & Bahasa Indonesia \\
\hline & & Bahasa Arab \\
\hline & & Bahasa Inggris \\
\hline \multirow{6}{*}{\multicolumn{2}{|c|}{$6 \quad$ Seni }} & Pembelajaran Seni \\
\hline & & Musik dan Suara \\
\hline & & Pendidikan Seni \\
\hline & & Rupa AUD \\
\hline & & Pembelajaran Seni \\
\hline & & Tari \\
\hline
\end{tabular}

Dari tabel di atas dapat dianalisis bahwa muatan kurikulum Prodi PIAUD telah disesuaikan dengan capaian pembelajaran pada setiap profil lulusan Prodi, dan jika dilihat secara umum relevansinya dengan kurikulum PAUD sudah relevan dengan apa yang dibutuhkan dalam kurikulum PAUD dimana yang dimaksudkan di sini adalah untuk dapat mencapai profil lulusan prodi baik profil utama yaitu menjadi guru pada lembaga PAUD dengan semua jenis layannanya maupun profil lulusan tambahan atau pendukung, dibutuhkan kurikulum yang relevan dengan kebutuhan di lapangan.

Kemudian muatan kurikulum yang sangat relevan dengan kebutuhan di dalam pelaksanaan pembelajaran PAUD dan menunjang guru dalam menjalankan profesinya yaitu yang berkaitan dengan model-model, metode pembelajaran, telaah kurikulum, pengembangan perangkat pembelajaran, media pembelajaran, teknologi pembelajaran serta praktek mengajar.

Berdasarkan tabel muatan kurikulum PAUD dan muatan kurkulum Prodi PIAUD sudah relevan, hanya saja menurut peneliti masih ada mata kuliah yang belum dapat memenuhi muatan pada kurikulum 
PAUD terutama yang merupakan ciri khas PAUD (Raudhatul Athfal) yang menonjolkan muatan Pendidikan Agama Islam di dalamnya ada hafalanhafalan surat-surat dalam Al-qur'an, pada muatan kurikulum Prodi PIAUD belum ada mata kuliah maupun capaian pembelajaran berkaitan dengan itu, sehingga dirasa penting untuk membuat mata kuliah Tabfidz dalam kurikulum Prodi PIAUD IAIN Curup.

Lebih lanjut lagi dengan mata kuliah pilihan wajib pada muatan kurikulum Prodi PIAUD dirasa perlu dimasukkan saja ke dalam mata kuliah wajib Program Studi, dikarenakan mata kuliah pilihan dilihat dari kajiannya sangat menunjang profil utama prodi yang meliputi mata kuliah : Matematika AUD, Pembelajaran Praktek Ibadah bagi Anak Usia Dini, Profesi Keguruan, Olahraga dan Senam Untuk Anak Usia Dini. Di samping itu mata kuliah tersebut sangat relevan dengan muatan kurikulum PAUD di Kabupaten Rejang Lebong yang memiliki karakteristik yang beragam.

Selain itu untuk mata kuliah evaluasi pembelajaran semestinya diturunkan ke dalam muatan mata kuliah Program Studi, mengingat jenis penilaian yang digunakan pada pendidikan anak usia dini memiliki ciri khas sendiri dibandingkan dengan jenjang pendidikan selanjutnya atau secara umum, sehingga peneliti merekomendasikan bahwa seyogyanya mata kuliah evaluasi diturunkan ke dalam mata kuliah keprodian dengan kajian di dalamnya membahas penilaian khusus bagi anak usia dini. Untuk lebih jelasnya sebagai berikut ini :

Tabel 4. Daftar Sebaran Mata Kuliah Prodi PIAUD yang Harus Dievaluasi

\begin{tabular}{clcl}
\hline No & \multicolumn{1}{c}{ Nama Mata Kuliah } & SKS & Rekomendasi Perubahan \\
\hline 1 & Matematika AUD & 2 & Dijadikan Mata Kuliah Wajib \\
\hline 2 & $\begin{array}{l}\text { Pembelajaran Praktek Ibadah } \\
\text { bagi AUD }\end{array}$ & 2 & Dijadikan Mata Kuliah Wajib \\
\hline 3 & Profesi Keguruan & 2 & Dijadikan Mata Kuliah Wajib \\
\hline 4 & $\begin{array}{l}\text { Olahraga dan Senam untuk } \\
\text { AUD }\end{array}$ & 2 & Dijadikan Mata Kuliah Wajib \\
\hline 5 & Evaluasi Pendidikan & 2 & $\begin{array}{l}\text { Diturunkan ke Mata Kuliah } \\
\text { Prodi }\end{array}$ \\
\hline 6 & Kurikulum Pembelajaran Anak & 2 & Ditambah Jumlah SKS \\
\hline
\end{tabular}


$\frac{\text { Usia Dini }}{\text { Dokumentasi : KKNI Prodi PLAUD IAIN Curup }}$

Menurut hemat peneliti pembagian mata kuliah dan penentuan dari jumlah sks tentunya harus mempertimbangkan tingkat kedalaman dan keluasan materi setiap mata kuliah terutama mata kuliah program studi. Lebih dari itu, dalam perumusan kurikulum harus melibatkan pakar di bidang Pendidikan Anak Usia Dini (termasuk ikut asosiasi program studi nasional) dan pakar kurikulum, dan melakukan tracer study sehingga mendapatkan input yang dapat menjadi perubahan serta pertimbangan dalam penyusunan kurikulum prodi PIAUD kedepan sehingga dapat mewujudkan profil lulusan prodi yang telah dirumuskan.

Berdasarkan uraian di atas, untuk menganalisis relevansi kurikulum prodi terhadap kurikulum PAUD diperlukan kajian lebih mendalam lagi, tidak hanya sebatas membandingkan aspek perkembangan dengan capaian pembelajaran serta struktur dan muatan mata kulian program studi saja, akan tetapi mengkaji apa saja kompetensi dan indikator pada setiap perkembangan pada pendidikan anak usia dini dan untuk pengembangan kurikulum Prodi PIAUD selain harus mengacu kepada Standar Nasional Perguruan Tinggi, lebih lanjut harus dibahas pada konsorsium keilmuan yang menyatu dalam kegiatan asosiasi program studi PIAUD seluruh Indonesia. Sehingga kurikulum yang diterapkan seragam walaupun tetap memasukkan ciri khas daerah masing-masing, akan tetapi perumusan dan penetapan capaian pembelajaran dilakukan dalam kegiatan asosiasi nasional, yang tentunya akan menjawab apa yang menjadi kebutuhan di lapangan kerja bagi lulusan prodi PIAUD itu sendiri.

Penjelasan di atas, tentunya menjadi harapan dan tantangan bagi prodi PIAUD kedepan, agar senantiasa memperbaiki kualitas pembelajaran melalui peninjauan kurikulum secara berkelanjutan yang disesuaikan dengan pengguna atau dunia kerja, sehingga profil lulusan yang telah dirumuskan bisa terwujud.

\section{KESIMPULAN}

Muatan kurikulum PAUD di Kabupaten Rejang Lebong yang mengacu pada Permen 58 tahun 2009 meliputi PAI, Bahasa, Kognitif, Fisik, Akhlakul Karimah, Kemandirian, Sosial Emosional. Sedangkan yang mengacu 
pada Permen 146 tahun 2014 yaitu aspek perkembangan Nilai Agama dan Moral, Fisik Motorik, Kognitif, Sosial Emosional, Bahasa dan Seni. Pelaksanaan kurikulum PAUD di Kabupaten Rejang Lebong secara umum telah sesuai dengan pedoman kurikulum yang berlaku hanya saja pada kegiatan belajar mengajar masih banyak yang belum menggunakan model pembelajaran yang seharusnya diterapkan, kemudian pendekatan belum secara implisit dimasukkan dalam rencana kerja harian yang disusun oleh guru. Relevansi kurikulum PAUD terhadap kurikulum Prodi PIAUD secara umum telah relevan, akan tetapi pada muatan dan penempatan pada komponen mata kuliah yang ditawarkan dan tingkat keluasan serta kedalamannya perlu dikaji ulang

\section{DAFTAR PUSTAKA}

Dewi Mahmudah, 2016. Implementasi Kurikulum 2013 Pendidikan Anak Usia Dini dalam Pembelajaran Yogyakarta : Prodi PGRA, Pascasarjana UIN Sunan Kalijaga.

Direktorat Pembinaan Pendidikan Anak Usia Dini Direktorat Jenderal Pendidikan Anak Usia Dini, Nonformal, dan informal Kementerian Pendidikan dan Kebudayaan tentang Kerangka Dasar dan Struktur Kurikulum 2013 Pendidikan Anak. Usia Dini

KKNI Prodi Pendidikan Islam Anak Usia Dini

Leli Halimah, 2016. Pengembangan Kurikulum Pendidikan Anak Usia Dini Bandung : PT Refika Aditama.

Peraturan Presiden Republik Indonesia Tentang Kerangka Kualifikasi Nasional Indonesia No 8 Tahun 2012

Pusat Kurikulum dan Perbukuan Badan Penelitian dan Pengembangan Kementerian Pendidikan dan Kebudayaan, 2015. Buku Panduan Pendidik Anak Usia 4-5 Tabun (Jakarta : Kemendikbud.

Roudlotun Ni'mah, Pengembangan Kurikulum Pendidikan Anak Usia Dini (Studi Kasus di TK Islam An- Nuur Purwosari Bojonegoro) Jurnal Pendidikan Islam : Al Ulya Volume 2 Nomor 1, edisi Januari - Juni 2017

Salinan Permendikas No 58 Tahun 2009 Tentang Standar Pendidikan Anak Usia Dini 
46| Ar-Riayah : Jurnal Pendidikan Dasar Vol. 3, No. 1, 2019

Salinan Lampiran I Peraturan Menteri Pendidikan dan Kebudayaan Republik Indonesia Nomor 146 Tahun 2014 Tentang Kurikulum 2013 Pendidikan Anak Usia Dini,

Suyadi \& Dahlia, 2017. Implementasi dan Inovasi Kurikulum PAUD 2013 (Bandung : PT Remaja Rosdakarya.

Sugiono, 2008. Metode Penelitian Pendidikan : Pendekatan Kuantitatif, Kualitatif, dan R\&D Bandung: Alfabeta.

Tri Andiyanto, Peran Guru Dalam Implementasi Kurikulum 2013: Studi Pada TK Mentari Kec. Abung Selatan Kab. Lampung Utara, Jurnal Elementary, Vol. 3 Edisi Januari-Juni 2017 